УДК 398 (091)

Щербак Світлана, кандидат філологічних наук, доцент кафедри української та світової літератур Криворізький державний педагогічний університет

\title{
ПОЕТИКА УКРАЇНСЬКИХ ЗАМОВЛЯНЬ ВІЙСЬКОВОЇ ТЕМАТИКИ
}

У статті пропонується розглянути поетику українських народних замовлянь воєнної тематики у контексті сучасного розвитку фольклористики. У статті акиентована увага 
на наукові праці, в яких піднімається питання тлумачення терміну замовляння, як одного із провідних малих фольклорних жанрів. Значну увагу приділено характеристиці сюжету замовляння. Простежено особливості художнього відтворення образу воїна у текстах замовлянь. Визначаються провідні особливості змістового та фуункиіонального навантаження відповідних міфологічних образів у текстах замовлянь.

Ключові слова: український фольклор, замовляння, поетика, ментальна символіка, міфологічний образ, художній образ, текст, сюжет, традииія.

\section{Shcherbak S. Poetics of Ukrainian military magic spells.}

In the article it is suggested to consider the poetics of the Ukrainian folk military spells in the context of modern development of specialist in folklore. In the article attention is focused on the scientific papers covering the problem of interpreting the term of a spell, as one of the leading minor folklore genres. Considerable attention is paid on the description of spell plot. The features of artistic creating the warrior character are traced in the texts of spells. The leading features of the semantic and functional loading of corresponding mythological characters are determined in texts of spells.

Keywords: Ukrainian folklore, spell, poetics, mental symbolics, mythological character, image, text, plot, tradition.

Серед великої української фольклорної спадщини, яка дійшла до нас 3 минулих літ і зберігається в архівних фондах, наукових виданнях, приватних колекціях й дотепер продовжує поповнюватися новими цінними надходженнями, особливе місце посідають твори магічного призначення, котрі в наукових колах та серед народу, як правило, називають замовляннями.

Одним із першоджерел, яке подає тлумачення поняття «замовляння» $є$ «Словарь української мови» Б. Грінченка: «замовляння - заговариваніе, заговоръ» [5, с. 67]. У «Словнику української мови» в 11 томах за редакцією І. К. Білодіда: «Дія за значенням замовля́ти; за марновірними уявленнями, магічні слова, вислови, щзо мають чаклунську силу $i$ якими замовляють кого-, щзо-небудь» [1, с. 217]. Схожі тлумачення цього терміну знаходимо у «Великому тлумачномк словнику сучасної української мови» за редакцією В. Т. Бусела, [4, с. 423], В. В. Жайворонок у словнику-довіднику «Знаки української етнокультури» [7, с. 235].

Тож, 3 плином часу поняття «замовляння» набуло більш конкретизованого, а з іншого боку, більш розширеного значення; виокремилася будова тексту замовляння.

У монографії «Український магічно-сакральний фольклор» I. Гунчик зазначає, що термін «замовляння» досліджували у своїх працях такі українські 
фольклористи, як: В. Антонюк, І. Березовський, В. Давидюк, М. Новикова, О. Павлов, Г. Сухобрус, Н. Шумада, Т. Шевчук; поруч із іншими термінами його впроваджували П. Єфименко, П. Іващенко, М. Комаров, М. Грушевський, Ф. Колесса, В. Петров, І. Огієнко [6, с. 30]. Вивченню фольклорного жанру замовляння присвячено низка наукових праць: М. Москаленко «Українські замовляння [9, с. 8], I. Гунчик [6, с. 30], Г. Бостан та І. Зварич [3]. Українські народні замовляння записували й досліджували: О. Малинка, В. Милорадович, Я. Новицький, М. Сумцов, В. Шухевич та інші.

Отже, аналітичний огляд словників та монографії дав можливість 3'ясувати сутність терміна «замовляння», котрий безпосередньо пов'язаний 3 дією «замовляти», а тому можемо узагальнити, що замовляння - це висловлені магічні слова, вислови, що мають чаклунську силу; усталена словесна формула, що зазвичай супроводжується відповідними діями.

Замовляння пов'язані з уявленнями про значущу магічну силу і дію слова. Магічного значення набула сама словесна формула. А функції замовлянь полягали у тому, щоб відвернути небажане або ж накликати бажане [16].

Замовляння хоч і $є$ найархаїчнішим пластом української фольклористики, але вони $є$ актуальними i до нині. Тож мета статті полягає у тому, щоб дослідити поетику українських замовлянь воєнної тематики.

Аналіз замовлянь, котрі пов'язані 3 темою війни, бійця, бою дав можливість визначити у цих текстах функціонування язичницької свідомості та культури, що дає підстави стверджувати їх появу ще до прийняття християнства.

Так досить поширеними та популярними в сучасний час, стали тексти бойових замовлянь для солдат та бійців, на силу, на перемогу. У сучасних умовах військових дій, які точаться уже не перший рік на Донбасі бійцям АТО потрібно уберегтися від ворожих куль, а їхнім близьким якимось чином хочеться захистити свою рідну та близьку людину від смерті, зробити все, щоб воїн залишився живим та неушкодженим. 
Зміст українських замовлянь на військову тематику, в яких йдеться про підготовку солдата до бою спрямований на такі факти убезпечення воїна:

«Обличчям на Північ звернусь - // Прабатькам своїм вклонюсь, // Слово за Рід тримаю, // Сили в Богів питаю! // Куля мене облітає, // Залізо мене обминає, // Вогонь та вода обтікають - // Ворогів моїх наганяють! // Шкіра моя - панцฺир з крищі, // Кров - з живої водиці, // Соколом хутко зметнусь, // Вовком перевернусь! // Вітрами вкриюся, // Снігами вмиюся, // За землю стою, // Свій Рід бороню! // Слава Україні!» [14].

Магічність наведеного замовляння полягає у звертанні до вищої сили зі своїм проханням: «Сили в Богів питаю!» [14]. Окрім цього, у тексті прослідковується зв'язок поколінь, а саме, шанобливе ставлення до предків: «Прабатькам своїм вклонюсь»[14]; відповідальність за життя своєї родини як продовження усього роду: «Слово за Pid тримаю», «Свій Рід бороню!» [14].

Настрій бійця зображується завдяки використанню таких поетичних засобів, як персоніфікація, метафоричність. Широко використовуються засоби порівняння воїна із птахом: «Соколом хутко зметнусь» [14], твариною: «Вовком перевернусь» [14], на основі метафоричних порівнянь 3 образами вітру та снігу: «Вітрами вкриюся, Снігами вмиюся» [14], що допомагає виокремити такі найважливіші риси воїна: спритність, уважність, кмітливість, швидкість. Отримання бажаного, тобто прагнення бути невразливим для ворога також зображується засобами персоніфікації та метафоричності: «Куля мене облітає, // Залізо мене обминає, // Вогонь та вода обтікають» [14].

Наступний приклад замовлянь покликаний додати сили бійцю, захистити свою Батьківщину і зробити воїна невразливим для ворога: «Ярило, силою вогняною, // Ярило, силою земною // У мій дім іди, // Силу мені принеси. // Хай мої руки // Стануть бистрії круки, // Хай мої ноги // Стануть міцнії остроги. // Зброю вояцьку мою освяти, // Дух войовничий за собою веди. // Хай я палаю тобою, Ярило, // В бій із тобою іду я сміливо!» [15].

Під час аналізу тексту замовлянь визначаємо міфологічний підтекст, котрий полягає у зверненні до язичницького божества Ярила. Персоніфікація 
образу прослідковується у дієсловах «іди», «принеси», тобто до нього звертаються як до живої людини: «Ярило, силою вогняною, // Ярило, силою земною // У мій дім іди, // Силу мені принеси» [15]. Метафоричність полягає у порівнянні рук солдата зі специфікою такого птаха, як крук: «Хай мої руки // Стануть бистрії круки» [15], а ніг - 3 острогами («Хай мої ноги // Стануть міцчнї̈ остроги» [15].

Гіперболізація та метафоричність притаманні також образу того воїна, хто промовляє цей текст, а саме: «Хай я палаю тобою, Ярило» [15], тобто іншими словами - це побажання бути відважним, сміливим, безстрашним, міцним.

У текстах замовлянь, котрі використовуються перед боєм та на випадок війни змальовується образ воїна, який $є$ сильним, відважним, непереможним: «Я завжди готов до бою, // Моє тіло - справжня зброя. // Б’ю, хватаю $i$ кидаю, // Ворогів перемагаю. // Сила в правді - // Справа Божа. // Ворогів я переможу! [37], або "Даною стелюся, // Стрибогом кручуся, // Велесом ламаю, // Ярилом палаю, // Триглавом накрию, // Рудою ворожою землю омию! // Вогонь беру, // На Прю іду. // Як вовк риче - // Триглав кличе // Гериьь танц̧ювати, // Вороженьків долати!» [15].

Є й такі замовляння, в котрих йдеться про захист від збройних уражень. Саме у таких текстах прослідковується розгортання цілісного сюжету: «3a лісами темними, за горами високими, де Вирій Землі-Макоші торкається, там стоїть кузня Сварогова.

У тій кузні Батько наш кує мечі крицеві, точить стріли залізні, ллє кулі свинцеві.

Стану я, Онук Дажбожий (ім'я), перед ликом Бога свого, скажу я Сварогові Батькові:

Ось я, Батечку, стою, як вірний син Богів Руських.

Руки мої тверді, як мечі воящькі, погляд мій влучний, як стріли Перунові, шкіра моя тверда, мов залізо щзита Твого.

Не бере мене ні куля, ні стріла, ні ніж, ані шабля ворожа. 
Минаю я пасток та сіток підступних,

яко єсть я Воїн Честі і Слави, і Дажбог на чолі раті намої іде.

I слово моє тверде, і слово моє міџчне, бо слово моє Камінь Алатир» [15].

Отже, у цьому тексті наявні міфологічні образи Перуна, Сварога, Дажбога, Макоші. Досить цікавим аспектом у замовлянні є зв’язок людського роду з божественним: «Стану я, Онук Дажбожий (ім'я)», «скажу я Сварогові Батькові: «Ось я, Батечку, стою, як вірний син Богів Руських» [15]. За рахунок засобів порівняння та гіперболізації передається пси фізіологічний стан воїна: «руки - мечі», «погляд - стріли», «шкіра - залізо». Усе це підсилює установку на зміцнення бойового духу воїна.

Аналізуючи текст замовлянь на перемогу, спостерігаємо у ньому турботу воїна за своєю родиною, прагнення перемоги, звільнення своєї рідної землі від ворога: «...Встану, умиюсь, благословляючись піду з дверей у двері, з воріт у ворота, в чистеє поле, на Схід Сония-Дажбога. А назустріч мені сім братів, сім вітрів Стрибожих. Ти, Боже-Дажбоже, освіти илях мій, ви, вітри Стрибожі, розвійте ворогів, як пил придорожній. Ляжу я пізно із зорею вечірньою на ложе хатнєє. А в хаті тій брати і сестрички, сильні козаченьки. Ви, козаченьки, підкоріть непокірних, байдужих зробіть прихильними, а я був би з вами сильним та смілим. Йду я корить непокірних, байдужих навертати, $i$ є я сильним і смілим. Ви ж, непокірні, покоріться, ви ж, байдужі, прихиліться. Замовляю я Воӥна межового, щзо йде на діло родове. Чур - слову кінещьь, а ділу вінец̧ь!» [15].

У цьому замовлянні поряд з язичницькими богами Дажбогом, Стрибогом є звертання й до природніх явищ та інших язичницьких образів: сімох братів вітрів Стрибожих, зорі вечірньої, а також братів і сестер козаченьків. Метафорично зображується побажання перемоги над ворогами: «Розвійте ворогів, як пил придорожній» [15].

Таким чином, замовляння аналізованого типу мають усі характерні риси цього жанру: магічно-сакральне значення, міфологічний підтекст, багаторазове використання повторів, образність, стрімкий розвиток сюжету, котрий надає 
замовлянням динамічності, що вимагає обов'язкого дійового супровіду, поетичність, художність, ритміка, діалогічність, просторове перенесення, архаїчність. Деякі елементи портретної характеристики у замовляннях передаються за рахунок порівнянь. Окрім цього, окличність форм замовлянь вказує на емоційне наснаження аналізованих текстів, що сприяє активізації бойового духу воїна.

\section{Література}

1. Білодід І. К. Словник української мови: в 11 тт. / АН УРСР. Інститут мовознавства; за ред. І. К. Білодіда / І. Білодід. - К. : Наукова думка, 1970 1980. - T. 3. - C. 217.

2. Бондаренко А. Культ воїна-звіра в давній період на території України / А. Бондаренко // Українознавство. - 201. - №2. - С. 209-216.

3. Бостан Г. К., Зварич I. М. / Енциклопедія сучасної України / http://esu.com.ua/search_articles.php?id=14856.

4. Бусел В. Т. Великий тлумачний словник сучасної української мови (з дод. і допов.) ; уклад. і голов. ред. В. Т. Бусел / В. Бусел. - К. ; Ірпінь : ВТФ «Перун», 2005. - 1728 с.

5. Грінченко Б. Словарь української мови ; упор. 3 дод. влас. матеріалу Б. Грінченко : в 4-х т. / Б. Грінченко. - К. : Вид-во Академії наук Української PCP, 1958. - Том 2. - C. 67.

6. Гунчик I. Український магічно-сакральний фольклор: структура тексту та особливості функціонування : монографія / І. Гунчик. - Львів : ЛНУ імені Івана Франка, 2011. - 232 с.

7. Жайворонок В. Знаки української етнокультури : Словник-довідник / В. Жайворонок. - К. : Довіра, 2006. - 703 с.

8. Лановик М., Лановик 3. Українська усна народна творчість : Підручник / М. Лановик, 3. Лановик. - К.: Знання-Прес, 2001. - С. 55-75.

9. Москаленко М. Українські замовляння / М. Москаленко. - К. : Дніпро, 1993. -309 c. 
10. Остроушко О. Українські замовляння-діалоги: структура, семантика, функціонування / О. Остроушко // Вісник Криворізького державного педагогічного університету : зб. наук. пр.; голов. ред. Ж. Колоїз - Кривий Ріг, 2008. - Вип. 2. - С. 52-57.

11.Павлов О. Д. Замовляння як вербальна магія : автореф. дис. канд. філол. наук : спеціальність 10.01.07 «Фольклористика» / О. Павлов. - К., 1999. $28 \mathrm{c}$.

12.Руснак I. Є. Український фольклор / I. Руснак. - Навчальний посібник, видавничий центр «Академія», 2010. - С. 46-51.

13. Шевчук Т. Магічна поезія замовляння. Еволюція ритуальнопоетичних формул / Т. Шевчук. - Родовід. - 1993. - № 5. - С. 10-12.

14.http://atomusik.blogspot.com/2015/04/blog-post_69.html// Бойові замовляння.

15.https://uamodna.com/articles/zamovlyannya-dlya-boyu-na-vypadok-viyny // Замовляння перед боєм та на випадок війни. 